\title{
The Relationships between Rumen Load and Diurnal Eating Pattern of Sheep Fed in Various Time of Access to Feed
}

Hisashi HIDARI

Laboratory of Animal husbandry, Obihiro University of Agriculture and Veterinary Medicine, Obihiro-shi 080

(Received October 6, 1980)

\begin{abstract}
Four fistulated sheep were offered hay cubes ad lib. for 24, 12, 6 and 3 hours once daily according to $4 \times 4$ Latin square design. The relationships between the diurnal eating patterns and the rumen load which were estimated by the torque values of rumen contents were analysed. As the daily time of access to feed was shortened, sheep tried to ingest feed more rapidly with long time for each meal and little rest. However, they could not completely fit their eating activities for given feeding conditions and reduced total daily feed intake. The mean values of daily intake of feed were 2413, 2086,1869 and $1502 \mathrm{~g}$ for $24,12,6$ and 3 -hr feedings respectively. The torque values of rumen contents reached the maximum level at the final satiety state (FSS) under all of the four feeding conditions. Regardless of differences in time of access to feed, these torque values at the FSS corresponded equally to $63 \%$ of the value of the rumen contents of each sheep estimated by fistula feeding techniques. The characteristics of eating behaviour before and after the PSS (primary satiety state) or FSS were explicable on the basis of the changes in the rumen load. These results seemed to suggest that the daily feed intake and diurnal eating behaviour of the sheep fed roughages are predominantly regulated by the maximum levels of their rumen load.
\end{abstract}

Jpn. J. Zootech. Sci., 52 (3):219-226, 1981

Much evidence to show the limiting effects of the rumen contents on the voluntary intake of roughages in ruminants has been provided by a great number of experiments. These results were summarized in various reviews ${ }^{1-3)}$. Transfer of ruminal digesta from a donor ${ }^{4,5}$, intraruminal addition of feed $^{6-9}$, or removal of digesta from the rumen ${ }^{4,5}$ have all resulted in some compensation in feed intake. Evans et al. ${ }^{10}$ ) reported that particle size, density and dry matter contents changed as the time after feeding elapsed. From the analysis of diurnal feeding behaviour of the sheep in free access, the author has proposed the hypothesis that the distribution of eating activity for the period of twenty-four hours was governed by the diurnal changes in the rumen contents ${ }^{11}$.

In the previous study ${ }^{12}$, It was shown that the torque values of rumen content were the representative of changes in the consistency of rumen digesta which accompanied ingestive behaviour. The present study aimed at determining the relationships between rumen load and the diurnal eating pattern of the sheep fed roughage in various feeding regimes. 


\section{Materials and Methods}

\section{Animals and treatments:}

Four fistulated wethers, $65 \mathrm{~kg}$ in average body weight, were assigned four experi . mental periods according to $4 \times 4$ Latin square design. In each experimental period, which consisted of 5 days of conditioning and 3 days recording, they were offered hay cubes ad lib. for $3,6,12$ or 24 hours once daily. Water and salt licks were available all the time. They were housed in individual pens equipped with the system for recording feeding behaviour previously described ${ }^{11}$. Jaw movements were monitored by a leather halter to which was attached a strain gauge, as described by Suzukr and HIDARI $^{13)}$.

\section{Measurements of rumen load:}

The rumen loads at the initiation and termination of feeding behaviour of the sheep were estimated from the torque values of rumen contents within 5 minutes after the beginning or end of each meal. After the feeding period, the torque values were measured at 3 hour intervals until the next feed offering. The measuring procedures with the torque meter fitted in the rumen cannula were in accordance with the manner previously reported ${ }^{12}$.

In the preliminary experiment, the maximum torque value of rumen content of each experimental wether was estimated by measuring the torque value when the maximum amounts of the hay cubes moistened with three fold synthetic saliva were added into the rumen by the fistula feeding technique. The rumen load was indicated as the ratio of a torque value to each maximum value in the preliminary experiment.

\section{Results}

Daily feeding behaviour:

Table 1 summarized the data on the diurnal eating activities of the sheep under

Table 1. Feeding behaviours of the experimental sheep fed in 3,6, 12 and 24-hr feedings once daily

$($ Mean \pm SD)

\begin{tabular}{lrrrr}
\hline \hline & \multicolumn{4}{c}{ Feeding period in a day } \\
\cline { 2 - 5 } & $24 \mathrm{hr}$ & $12-\mathrm{hr}$ & $6-\mathrm{hr}$ & $3-\mathrm{hr}$ \\
\hline Feed intake (g) & $2413^{\mathrm{a}} \pm 244$ & $2086^{\mathrm{ab}} \pm 207$ & $1869^{\mathrm{b}} \pm 86$ & $1502^{\mathrm{c}} \pm 118$ \\
$\begin{array}{l}\text { Time spent eating (min) } \\
\text { Number of eating }\end{array}$ & $180^{\mathrm{ab}} \pm 21$ & $206^{\mathrm{a}} \pm 65$ & $144^{\mathrm{bc}} \pm 22$ & $98^{\mathrm{c}} \pm 17$ \\
$\begin{array}{c}\text { periods* } \\
\text { The longest eating } \\
\text { period in a day (min) }\end{array}$ & $16 \pm 3$ & $10 \pm 2$ & $5 \pm 1$ & $3 \pm 1$ \\
$\begin{array}{c}\text { The rate of eating } \\
\text { (g/min) }\end{array}$ & $34^{\mathrm{a}}$ & $64^{\mathrm{ab}}$ & $69^{\mathrm{ab}}$ & $76^{\mathrm{b}}$ \\
$\begin{array}{l}\text { Time spent rumination } \\
\text { (min) }\end{array}$ & $548 \pm 76$ & $546 \pm 23$ & $514 \pm 53$ & $518 \pm 33$ \\
$\begin{array}{l}\text { Water intake (1) } \\
\text { Drinking times }\end{array}$ & $5.1 \pm 0.5$ & $5.7 \pm 1.0$ & $4.7 \pm 0.7$ & $3.6 \pm 1.0$ \\
\hline
\end{tabular}

*: Except for periods shorter than $10 \mathrm{~min}$. a, b, c: Means with different superscript differ significantly $(P<0.05)$. 


\section{Rumen Load and Eating Behaviour}

the experimental feeding regimes. The daily feed intake and the time spent eating decreased with the restriction of daily time of access to feed $(P<0.05)$. The data of the longest eating period in a day and the rate of eating seemed to show that the sheep tried to be adapted to the feeding condition given. The time spent eating was about $54,40,29$ and $13 \%$ of time allowances for eating 3,6, 12 and 24 -hr feeding in a day respectively.

The mean size of a meal was calculated as 501, 374, 209 and $151 \mathrm{~g}$ for the 3,6 , 12 and 24 -hr feedings, respectively. The rumination time in a day did not change with the four feeding conditions as compared with the changes in the time spent eating. The time of drinking showed no specific trends related to the time of access to feed although there were some individual variances owing to their drinking habits.

\section{Diurnal changes in eating and ruminating activities:}

From the records of jaw movements, the diurnal changes in the time spent eating and rumination were illustrated in Figure 1. The proportion of time spent eating in an hour immediately after the feed offering, increased with the reductions in time allowance for eating. No matter how long the time of access to feed was, ruminating activities were almost entirely concentrated from midnight to dawn. The pattern of rumination for twelve hours from 20:00 to 8:00 was similar in the three regime of limited access to feed.

Meal sizes and satiety levels:

From the previous study, it is suggested that there are two levels of satiety state

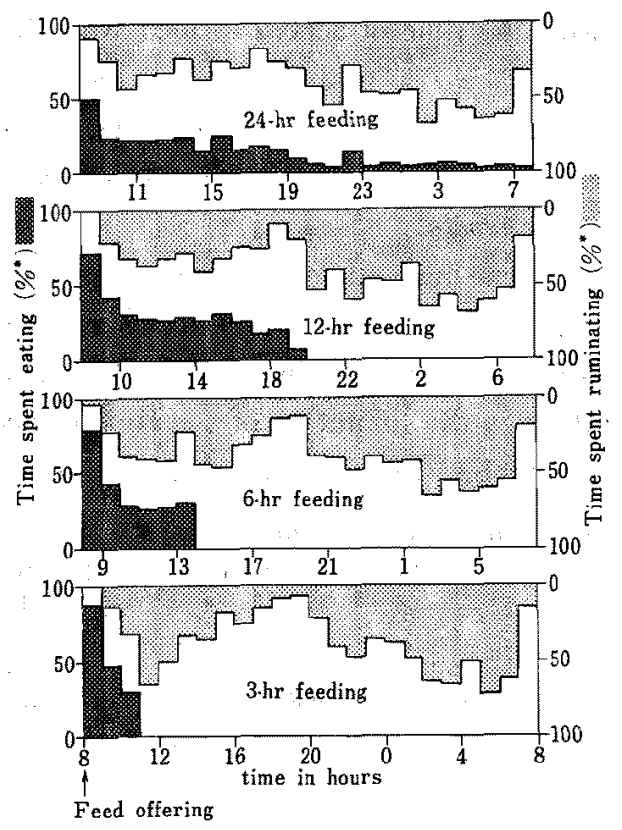

Fig. 1. The histograms of ingestive behaviours of the sheep under the four feeding conditions. *: As the percentage of the time spent for each activity within one hour. 
HIDARI

Table 2. The relationships between the satiety levels and size of a meal in the sheep fed under four experimental conditions

\begin{tabular}{|c|c|c|c|c|}
\hline \multirow{2}{*}{\multicolumn{2}{|c|}{$\begin{array}{l}\text { Daily time of } \\
\text { access to feed }\end{array}$}} & \multicolumn{3}{|c|}{ Satiety level } \\
\hline & & Before PSS & $\begin{array}{c}\text { Between PSS } \\
\text { and FSS }\end{array}$ & After FSS \\
\hline \multirow{2}{*}{$24-\mathrm{hr}$} & $\begin{array}{l}\text { Size of } \\
\text { a meal }(g)\end{array}$ & $343 \pm 86$ & $160 \pm 43$ & $85 \pm 54$ \\
\hline & $\begin{array}{l}\text { Number of } \\
\text { meals }\end{array}$ & 2 & 8 & 6 \\
\hline \multirow{2}{*}{ 12-hr } & $\begin{array}{l}\text { Size of } \\
\text { a meal (g) }\end{array}$ & $502 \pm 234$ & $179 \pm 70$ & $70 \pm 37$ \\
\hline & $\begin{array}{l}\text { Number of } \\
\text { meals }\end{array}$ & 2 & 8 & 1 \\
\hline \multirow{2}{*}{$6-\mathrm{hr}$} & $\begin{array}{l}\text { Size of } \\
\text { a meal (g) }\end{array}$ & $616 \pm 91$ & $246 \pm 106$ & $7 I \pm 3 I$ \\
\hline & $\begin{array}{l}\text { Number of } \\
\text { meals }\end{array}$ & 2 & 2 & 一 \\
\hline \multirow{2}{*}{$3-\mathrm{hr}$} & $\begin{array}{l}\text { Size of } \\
\text { a meal (g) }\end{array}$ & $717 \pm 129$ & $100 \pm 173$ & $51 \pm 64$ \\
\hline & $\begin{array}{l}\text { Number of } \\
\text { meals }\end{array}$ & 2 & - & - \\
\hline
\end{tabular}

in the diurnal eating patterns of sheep fed in free access. Adopting the definition of these satiety states (PSS and FSS) for the eating patterns under the four experimental feeding schemes, the relationships between the eating activities and the satiety levels were summarized in Table 2.

The meal sizes before the PSS were increased with the reduction of the time of access to feed. The shorter the time of access to feed was, the larger was the percentage of feed intake before the PSS to the daily feed intake. They were 28.4, 48.1, 65.9 and $95.5 \%$ according to $24,12,6$ and 3 -hr feeding, respectively. The time at the PSS and FSS in the 3 and 6-hr feeding seemed to overlap.

\section{Rumen load and satiety levels:}

The rumen load at the time immediately before feeding, the PSS and the FSS are shown in Table 3. The figures represent the relative values to the torque values of rumen contents at the fistula feeding experiment. The torque values before feed offering went down according to the limitation of the time of access to feed. On the other hand, the values at the FSS did not vary with the time of access to feed and

Table 3. The mean values of rumen load at PSS, FSS and immediately before feeding for the sheep fed in four experimental feeding regimes

$(\% ;$ Mean $\pm \mathrm{SD})$

\begin{tabular}{lrcc}
\hline Feeding regime & $\begin{array}{c}\text { Immediately } \\
\text { before feeding }\end{array}$ & PSS & FSS \\
\hline 24-hr feeding & $20.7 \pm 11.6$ & $34.4^{\mathrm{a}} \pm 6.4$ & $63.4^{\mathrm{b}} \pm 14.0$ \\
$12-\mathrm{hr}$ & $6.8 \pm 8.2$ & $37.9^{\mathrm{a}} \pm 12.2$ & $60.2^{\mathrm{b}} \pm 10.7$ \\
6 - $\mathrm{hr}$ & $3.6 \pm 6.7$ & $52.6^{\mathrm{b}} \pm 16.6$ & $61.9^{\mathrm{b}} \pm 14.8$ \\
$3-\mathrm{hr}$ & $0.2 \pm 0.5$ & $64.4^{\mathrm{b}} \pm 14.7$ & $65.6^{\mathrm{b}} \pm 16.7$ \\
\hline
\end{tabular}

$a, b$ : Means with different superscript differ significantly $(P<0.05)$. 


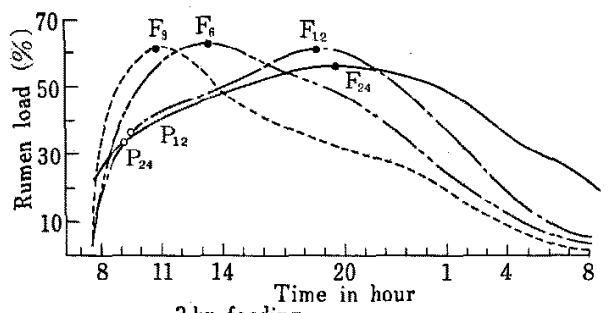

- - - - 3.hr feeding

- - - - $6 \cdot \mathrm{hr}$ feeidng $12 \mathrm{hr}$ feeding

24-hr feeding

$\mathrm{P}_{\mathrm{n}} \mathrm{O}:$ Primary satiety state, $\mathrm{F}_{\mathrm{n}} \bullet:$ Final satiety state,

$\mathrm{n}$ : Time of access to feed.

Fig. 2. The diurnal changes in the rumen load of the sheep fed under the four experimental feeding regimes.

were constantly maintained at about $63 \%$ in contrast with the daily feed intake. For the 12 and 24-hr feedings, they had a temporary satiation within about 100 min after the daily allowance was supplied (PSS). The torque values at the PSS were equivalent to $54.3,63.0 \%$ of the values at the FSS. These percentages were larger than the ratios of feed eaten until the PSS to the daily intake.

Figure 2 showed traces of the diurnal changes in the rumen load of the sheep fed in the four experimental feeding regimes. The maximum level of rumen load in a day appeared on each FSS arriving under all of the four feeding conditions. At the 24 and 12-hr feeding, the rumen load increased rapidly until arriving at PSS, and went up with a gentle slope between the PSS and FSS. After arriving at FSS, it decreased gradually toward the levels immediately before feed offering. While on the 6 and 3 -hr feeding, no such changes in the rumen load at PSS arriving were visible. The rumen load went up to the peak at the FSS with one rush.

\section{Discussion}

The sheep ate more rapidly with the longer eating periods in 3-hr feeding than 24-hr feeding. However, they could not eat as many hay cubes as in free access to feed all day. It is noteworthy that they spent only $98 \mathrm{~min}$ for eating in spite of being permitted to eat for $180 \mathrm{~min}$ (Table 1). Freer et al. ${ }^{14)}$ and SuzukI et al. ${ }^{15)}$ also found similar increases in the rate of eating with cows, when the daily time of access to hay was reduced from 24 hours to either 4.5 or 4 hours. There must be reasons why the sheep could not eat any more feed in spite of having available time for eating. FAIChNEY ${ }^{16)}$ and Whitelaw et al. ${ }^{17)}$ found that sheep or heifers fed once daily make a large fluctuation in the rumen $\mathrm{pH}$ and VFA concentrations in contrast to the animals fed with multi-divided feeding.

SASAKI et al. ${ }^{18)}$ observed that the sheep given a chance to eat once daily to satiation showed an acidotic state during eating. Such changes in the physiological factors seem to have resulted from the ruminants being forced to eat rapidly. It is probable that these changes in the physiological factors affect their eating behaviour. The pres- 
ent study has intended to show whether the physical characteristics of rumen contents prevent the sheep from eating as much as in free access to feed all day.

In spite of the decrease in daily intake due to the restriction of daily time of access to feed, sheep showed neither decreases in time spent ruminating nor changes in the pattern of ruminating activities during the midnight. It is well known that the time spent in rumination is related to feed intake ${ }^{19,20}$, particle size $\mathrm{e}^{21}$, and chemical compositions of feed ${ }^{22,23)}$. From the results of the present study, sheep had the drive to ruminate immediately after the feeding period, especially in the 3-hr feeding (Figure 1). It may be possible that when the access was restricted the feed was chewed less during eating and provided a greater amount of stimulation to ruminate while in the rumen.

The increase in the rate of eating caused by the restriction of eating time must have induced a high proportion of coarse particles of feed in the rumen. As above mentioned, Evans et al. ${ }^{10)}$ found that in cows the rumen contents immediately after feeding have many coarse particles. BLAXTER et al. ${ }^{24)}$ analysed the relation between the digestibility of feed and its passage through the gut of the sheep, and estimated the gut contents in terms of indigestible residues ("ballast") or dry matter present in the gut ("fill"). Then the latter concluded that the maximal appetite of animals for feed is determined to a considerable extent by the feed residues present in their digestive tracts. Campling et $a .^{25}$ ) showed that the differences in the voluntary intake of hay and straw in cows were explicable on the basis of the differences in the retention time of feed residues in their digestive tract, or the amounts of digesta in the rumen.

On the assumption that the voluntary feed intake in ruminants is regulated by the amounts of the contents in the digestive tracts, the changes in the rumen content with time should correspond to the diurnal pattern of eating behaviours. The torque values measured in the present experiment have represented two physical factors included in the rumen digesta, namely the amount of dry matter content and the sizes of feed particles, which changed consecutively for the process to achieve their daily feed intake. The rumen load estimated from the torque values maintained the same levels at the FSS, i. e. nearly the end of daily feeding activities, in the sheep fed in all of the times of access to feed (Table 3). Therefore the differences in the daily intake of the hay cubes according to the feeding regimes might be due to not only the amounts of rumen contents but also to their particle sizes. The values of the rumen load at the FSS may suggest that the termination of eating activities in a day depends on the stress of mechanical stimulation to the rumen epitheriums by the rumen contents.

If we define the satiety state as starting to rest more than 30 minutes one time or having no longer periods of eating than 30 minutes consecutively for the sheep fed in free or limited access to feed, the variation of rumen load from the temporary satiated state (PSS) to the final satiated state in a day was widely distributed from 36 to $63 \%$ of the individual maximum level of torque value of each experimental sheep. This is likely due to the flexibility of the rumen capacity and the existence of the regulation mechanism of appetite rather than the rumen load. 
As mentioned in the result, however, the ratios of torque value at the PSS to the FSS were larger than those of feed eaten until the PSS to the daily intake. This may suggest that the rumen load started to influence on the control of feed intake since the PSS. The rumen load had neither decreased below, nor exceeded that range in the satiated state from the PSS to the FSS. Although it should be considered that many physiological factors affect the regulation mechanisms of the feeding behaviours of sheep, the diurnal eating pattern of the sheep in this experiment seems to be fairly explicable on the basis of the changes in the rumen load. The intensive eating activities of the sheep seemed to enable to quickly achieve the level of rumen load which appeared at the initiation of satiety state. The sheep regulated the size of eating activities to maintain the levels of the rumen load between the PSS and FSS. After the FSS, their eating activities were restrained to prevent the rumen load from exceeding the levels of the satiated state.

Thus the results presented here suggest the close relation between the diurnal eating pattern and the physical characteristics of the rumen contents in the sheep fed hay cubes in free access.

\section{Acknowledgement}

The author wishes to thank Dr. S. Suzuki for much encouragement and advice, and is also indebted to $\mathrm{Mr}$. H. Hiraishi for experimental assistance.

\section{References}

1) Balch, C. C. and R. C. Campling, Nutr. Abs. and Rev,, 32:669-686. 1962

2) Baile, C. A. and J. M. Forbes, Physiol. Rev,, 54: 160-214. 1974.

3) Hidari, H., Jpn. J. Zootech. Sci., 50: 835-844. 1979.

4) Campling, R. C. and C. C. Batch, Br. J. Nutr., 15: 523-530. 1961.

5) Cark, S. B. and D. R. Jacobson, J. Dairy Sci., 50: 1814-1818. 1967.

6) Welton, R. F. and B. R. Baumgardt, J. Dairy Sci,, 53: 1771-1774. 1970.

7) Weston, R. H., Aust. J. Agric. Res., 17: 939-954. 1966.

8) Van Nieckerk, A. I., J. F. D. Greenhalgh and G. W. Reid, Br. J. Nutr., 30: 95-105. 1973.

9) Greenhalgh, J. F. D. and G. W. Reid, Br. J. Nutr., 26: 107-116. 1971.

10) Evans, E. W., G. R. Pearce, J. Burnetr and Susan L. Pillinger, Br. J. Nutr., 29: 357-376. 1973.

11) Hidari, H., Jpn. J. Zootech. Sci., 47: 283-291. 1976.

12) Hidari, H., Jpn. J. Zootech. Sci, 50: 402-410. 1979.

13) Suzuki, S. and H. Hidari, Jpn. J. Zootech. Sci., 44: 216-221. 1973.

14) Freer, M., R. C. Campling and C. C. Balch, Br. J. Nutr., 16：279-295. 1962.

15) Suzurr, S., Y.Shinde and H. Hidari, Jpn. J. Zootech. Sci., 41: 423-429. 1970.

16) Faichney, G. J., Aust. J. Agric. Res,, 19: 813-819. 1968.

17) Whitelaw, F. G., Hyldgaard-Jensen, R. S. Reid and M. G. Kay, Br. J. Nutr., 24: $179-195$. 1970.

18) Sasaki, Y., S. Watanabe, Y. Sato, S. Kato and T. Tsuda, Jpn. J.Zootech. Sci., 45: 8-13, 1974.

19) Welch, J.G. and A. M. Smith, J. Anim. Sci., 28: 827-830. 1969.

20) Harumoto, T. and M. Kato, Jpn. J. Zootech. Sci., 50: 155-160. 1979.

21) Supweeks, E. M., M. E. McCullough, L. R. Srsk and S. E. Law, J. Anim. Sci., 41: $219-224$. 1975.

22) Welch, J.G. and A. M. Smith, J. Anim. Sci., 33: 472-475. 1971.

23) Dulphy, J. P. and C. Demarquilly, Annal. de Zootech., 23: 193-212. 1974.

24). Blaxter, K. L., N. McC. Graham and F. W. Wainman, Br. J. Nutr., 10: 69-91. 1956.

25) Campling, R. C., M. Freer and C. C. Balch, Br. J. Nutr., 15: 531-540. 1961. 


\title{
めん羊の日周採食行動と第一胃内飼料充滿度との関係
}

\author{
左久 \\ 査広音産大学, 帯広市 080
}

めえ羊の第一罢内容物の物理的性質が 1 日の採食パタ 一ン形成に果す役割を明らがする目的で, 時閶制限給 飼を行ない，採食行動の適応と第一胃内容物の堅さとの 関係を娭討した，第一胃フィステル装着めえ羊 4 頭に1 日1回 3，6，12，24 時間給餇をラテン方格法に侹って施 し、ーイキューブを給与した．第一胃フィステルに取付 けたトルクメータで第一䏴内容物の堅さを経時的に測定 し, 第一胃内飼料充满度の日周变動を推定した. 採食,

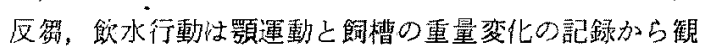
察した。めん羊は給的時間を制限されると、1 回の採食 の長さを伸ばし，探食速度をあげて1日採食量空維持し ようこする傾向がみられた.しかし，1日採食量は給飼
侍間の短䋩之共化隇少し，1日反㫚時間には变化がなか った. 1 日の採食行動の終了時に近いFSS 到達時の第一

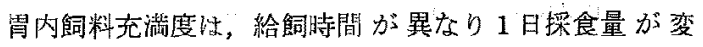
化しても同じ水準に維持されていた，その值住各めん 羊に fistula feeding で满腹させた時の飼料充淦度の約 63\%に相当した。これらのことから，時間制限給飼にお けるめん羊の 1 日採食量の決定には FSS 時の飼料古満 度が深く関与していることが示焧された。、 邓，め羊の 1 日の採食パターン形成は第一盟内容物の堅さの相対値 である飴料充満度の变化によってよく説明できるむのと 思われた。蓄会報，52(3)：219-226，1981 